\title{
Refining the palaeoecology of lacustrine testate amoebae: insights from a plant macrofossil record from a eutrophic Scottish lake
}

\author{
Stephen V. Prentice · Helen M. Roe • Helen Bennion • Carl D. Sayer • \\ Jorge Salgado
}

Received: 4 November 2016/Accepted: 21 April 2017/Published online: 12 June 2017

(C) The Author(s) 2017. This article is an open access publication

\begin{abstract}
Arcellinida (lobose testate amoebae) preserve well in lake sediments and have shown great potential as palaeolimnological indicators, but a limited understanding of their ecology prevents more indepth interpretations of both contemporary and fossil assemblages. Loch Leven, Scotland, has a well-documented history of nutrient-enrichment and associated lake biological change, creating a temporal gradient along which testate amoeba ecology can be investigated. Plant macrofossil data from a dated sediment core (LEVE14) indicate that a transition from oligomesotrophic to eutrophic conditions occurred over at least the last 200 years, enabling direct comparisons to be drawn with fossil testate amoeba assemblages from the same core. Cluster analysis and principal
\end{abstract}

Electronic supplementary material The online version of this article (doi:10.1007/s10933-017-9966-y) contains supplementary material, which is available to authorized users.

S. V. Prentice $(\varangle) \cdot$ H. M. Roe

School of Natural and Built Environment, Queen's University Belfast, Belfast BT7 1NN, UK

e-mail: sprentice01@qub.ac.uk

H. Bennion - C. D. Sayer

Department of Geography, Environmental Change

Research Centre, University College London, Gower

Street, London WC1E 6BT, UK

\section{J. Salgado}

Laboratorio de Palinología y Peleoecología Tropical, Departamento de Ciencias Biológicas, Universidad de Los

Andes, Carrera Primera \# 18A - 12, Bogotá, Colombia components analysis show that testate amoebae and macrophytes responded synchronously to an early phase of nutrient-enrichment after ca. AD 1200, and to anthropogenic water-level lowering and further enrichment after ca. AD 1830. The results of indicator species analysis (IndVal) support the suggestion inferred previously that Cucurbitella tricuspis is an indicator of nutrient-enrichment, while the association of some less abundant taxa, specifically Difflugia amphora and Mediolus corona, with eutrophic environments is also corroborated. Overall, the testate amoeba assemblage response appears to reflect a complex interaction of factors which were ultimately driven by eutrophication. These include variations in microhabitat associated with changing plant structure and sedimentary conditions influenced by macrophyte community succession. In particular, a shift from an oligo-mesotrophic macrophyte assemblage composed of isoetid plants to one dominated by Potamogeton spp. and dense stands of Characeae is suggested to influence the relative proportions of sediment dwelling and plant-associated testate amoebae. The results highlight the utility of testate amoebae as benthic indicators of lake nutrient-enrichment and demonstrate the value of using multi-proxy palaeolimnological data to refine the ecology of lesser-studied palaeoecological groups.

Keywords Arcellinida - Eutrophication · Plant macrofossils · Shallow lake $\cdot$ Loch Leven ·

Palaeolimnology 


\section{Introduction}

The fossil remains of many biological groups preserve well in lake sediments and have been used successfully to reconstruct long-term ecological changes in shallow lakes, especially associated with eutrophication. These include plant macrofossils (Davidson et al. 2005; Sayer et al. 2010b), diatoms (Anderson et al. 1993; Bennion et al. 2011), cladocerans (Brodersen et al. 1998; Davidson et al. 2011), chironomids (Brooks et al. 2001; Zhang et al. 2012) and non-pollen palynomorphs (NPP) (Drljepan et al. 2014; Volik et al. 2016). Due to a lack of instrumental monitoring of lake conditions, palaeolimnological approaches are essential for assessing long-term trends, determining pre-disturbance conditions (Bennion et al. 2011) and for informing conservation strategies (Kowalewski et al. 2013). Multi-proxy approaches are increasingly being used in palaeolimnological studies (Sayer et al. 2010b; Wiik et al. 2015; Sayer et al. 2016) to provide a more comprehensive understanding of communitywide changes resulting from eutrophication and other anthropogenic drivers in lakes, including the sequence and mechanisms of biological change (Sayer et al. 2010a; Bennion et al. 2015). Typical groups used in multi-proxy work include diatoms, plant macrofossils, cladocerans and algal pigments and invariably the addition of each group enhances understanding. To further this research it is important to explore other potential indicators of changing lake biological structure and ecology and one such group are testate amoebae.

Testate amoebae are a group of shelled protozoans common to a range of aquatic and terrestrial environments, from lakes and ponds to saltmarshes and peatlands (Roe et al. 2002; Roe and Patterson 2006; Amesbury et al. 2016). In lake environments lobose forms of the group dominate (Rhizopoda; Arcellinida). Testate amoebae are useful in palaeolimnological studies due to their rapid generation times, enabling high-resolution sampling (Medioli and Scott 1983), and in particular good preservation and high abundances in sediments (McCarthy et al. 1995). In addition, as bottom-dwelling organisms, they occupy a critical habitat for which environmental reconstructions are widely lacking, excepting chironomid-oxygen studies (Quinlan and Smol 2002). Despite an expanding geographical range of lake testate amoeba research that initially centred on Europe (Asioli et al.
1996; Wall et al. 2010b) and North America (Collins et al. 1990; Patterson and Kumar 2002; Reinhardt et al. 2005) and more recently Asia (Ju et al. 2014) and South America (Caffau et al. 2015), UK lake studies are very few (Ellison 1995; Wiik et al. 2015). Within the UK, research has largely been confined to peatlands and saltmarshes, with the focus generally on quantitative palaeohydrological reconstructions (Swindles et al. 2009) and sea-level change (Gehrels et al. 2001; Barnett et al. 2017). In lakes, testate amoebae are likely to be especially sensitive to changes at the sediment-water interface, such as water temperature (Collins et al. 1990), salinity (Roe and Patterson 2006; 2014), metal contamination (Kihlman and Kauppila 2012; Nasser et al. 2016), pH (Patterson and Kumar 2000a; Escobar et al. 2008; Patterson et al. 2013), dissolved oxygen (Drljepan et al. 2014) and/or variations in substrate characteristics (Reinhardt et al. 2005; Kihlman and Kauppila 2012). In summarising early research (Schönborn et al. 1965; Schönborn 1967; Laminger 1973), Tolonen (1986) noted that, amongst other drivers, eutrophication may be an important factor controlling testate amoeba assemblages. Recent studies of the modern distribution of lobose forms of testate amoebae in lakes along urban-rural (Roe et al. 2010) and nutrient (Ju et al. 2014) gradients have extended this early work and confirmed that a strong association exists between testate amoebae and phosphorus and nitrogen. Down-core analyses of testate amoeba assemblages have been used to infer lake trophic status change, both qualitatively (Reinhardt et al. 2005; Qin et al. 2009; Drljepan et al. 2014) and quantitatively (Patterson et al. 2012). However, a limited understanding of testate amoeba ecology, in particular the causal mechanisms for community change associated with eutrophication and other processes, prevents a more in-depth interpretation of both modern and fossil assemblages.

This paper aims to improve the understanding of testate amoeba ecology within the context of a shallow, eutrophic lake with a well-documented history of nutrient-enrichment and associated lake biological change, while expanding the limited body of UK lake testate amoeba research. Our focal site, Loch Leven, has been the subject of several previous palaeolimnological investigations, including analyses of plant macrofossils (Salgado et al. 2010) and diatoms (Bennion et al. 2012) which reveal a history of 
enrichment from oligo-mesotrophic to eutrophic conditions. Furthermore, long-term monitoring of water chemistry, macrophytes, algae, zooplankton, macroinvertebrates, fish and wildfowl, spanning more than 40 years (May and Spears 2012), permit a detailed understanding of eutrophication in Loch Leven and subsequent recovery in the late twentieth century. The objectives of this research are: (i) to compare the timings of changes in the testate amoeba record with those of existing plant macrofossil records from the same core and with wider knowledge of lake changes derived from palaeo-diatom studies and long-term monitoring data; and (ii) based on these comparisons, to provide an improved understanding of testate amoeba ecology.

\section{Study site}

Loch Leven $\left(56^{\circ} 11^{\prime} 55^{\prime \prime} \mathrm{N}, 3^{\circ} 22^{\prime} 46^{\prime \prime} \mathrm{W}\right)$ is a large $\left(13.3 \mathrm{~km}^{2}\right.$ ), shallow (mean depth $3.9 \mathrm{~m}$ ), lowland (107 m.a.s.1.) lake situated near the town of Kinross in central Scotland (Fig. 1). The loch is currently alkaline and moderately eutrophic, with mean annual average total phosphorus (TP) and chlorophyll $a$ (chl a) concentrations (2008-2010) of 33 and $21 \mu \mathrm{g} \mathrm{L}^{-1}$, respectively (Dudley et al. 2012a). The surrounding catchment comprises $80 \%$ agricultural land (Castle et al. 1999), with water entering the loch via four main inflows (Fig. 1) from farms, villages and the adjacent town of Kinross.

Historical (Jupp et al. 1974; Dudley et al. 2012b) and palaeoecological (Haworth 1972; Salgado et al. 2010; Bennion et al. 2012) records reveal progressive nutrient-enrichment in Loch Leven throughout the nineteenth and twentieth centuries from oligo-mesotrophic to eutrophic conditions. In particular, the loss of Isoetes lacustris prior to ca. 1850 and a shift to an elodeid dominated macrophyte community post1910 indicate an early influence of eutrophication (Salgado et al. 2010). A marked shift to a more planktonic diatom community throughout the twentieth century is also evident in several sediment cores from the site (Haworth 1972; Bennion et al. 2012), particularly since around 1940 (Bennion et al. 2012). This suggests enhanced pelagic primary production relative to the benthic zone caused by increased turbidity impeding photosynthesis on the lakebed.

The main sources of nutrients to the loch are agricultural runoff and sewage discharge (May et al.
2012). Consequently, a catchment management plan was implemented in the late 1980s and 1990s aimed at reducing point sources of pollution (D'Arcy et al. 2006), which resulted in a $60 \%$ reduction in catchment TP (May et al. 2012). This can be attributed to a number of factors, including the upgrading of sewage treatment works and the cessation of effluent discharge from a woollen mill in 1988 (D'Arcy et al. 2006). In addition to a dynamic trophic history, Loch Leven has undergone significant morphological change as water levels were lowered by $1.5 \mathrm{~m}$ in 1830 to permit agricultural expansion along its shores (Morgan 1970). This was achieved by cutting a new channel for the loch's main outflow, the River Leven.

\section{Methods}

Core collection and chronology

As part of a previous palaeolimnological study (Salgado et al. 2010), a 141-cm shallow-water $(2.2 \mathrm{~m})$ sediment core (LEVE14) was collected in May 2006 off the eastern shore of St. Serf's Island in the southeast corner of Loch Leven (Fig. 1), using an adapted Livingstone (7.4-cm diameter) piston corer. A further sediment core (LEVE11) was collected from a more central lake location (Fig. 1) at a depth of $4 \mathrm{~m}$ as part of a palaeolimnological study investigating diatom responses to eutrophication and lake recovery (Bennion et al. 2012). Diatom assemblages from core LEVE11 are used in this study to provide further context for understanding lake-wide changes in eutrophication, while core LEVE14 provided material for testate amoeba analysis and a direct comparison with the plant macrofossil record of Salgado et al. (2010).

Core LEVE14 was dated radiometrically using ${ }^{210} \mathrm{~Pb},{ }^{226} \mathrm{Ra}$ and ${ }^{137} \mathrm{Cs}$ analysis, the results of which are fully described in Salgado et al. (2010). In an attempt to further constrain the chronology of the LEVE14 core, we obtained three accelerator mass spectrometry (AMS) ${ }^{14} \mathrm{C}$ dates from the middle and basal sections of the core. Owing to a lack of terrestrial macrofossils, bulk sediment and charcoal samples were selected for AMS dating (Electronic Supplementary Material ESM1), which was undertaken at the ${ }^{14}$ CHRONO Centre for Climate the Environment and Chronology, Queen's University Belfast. 


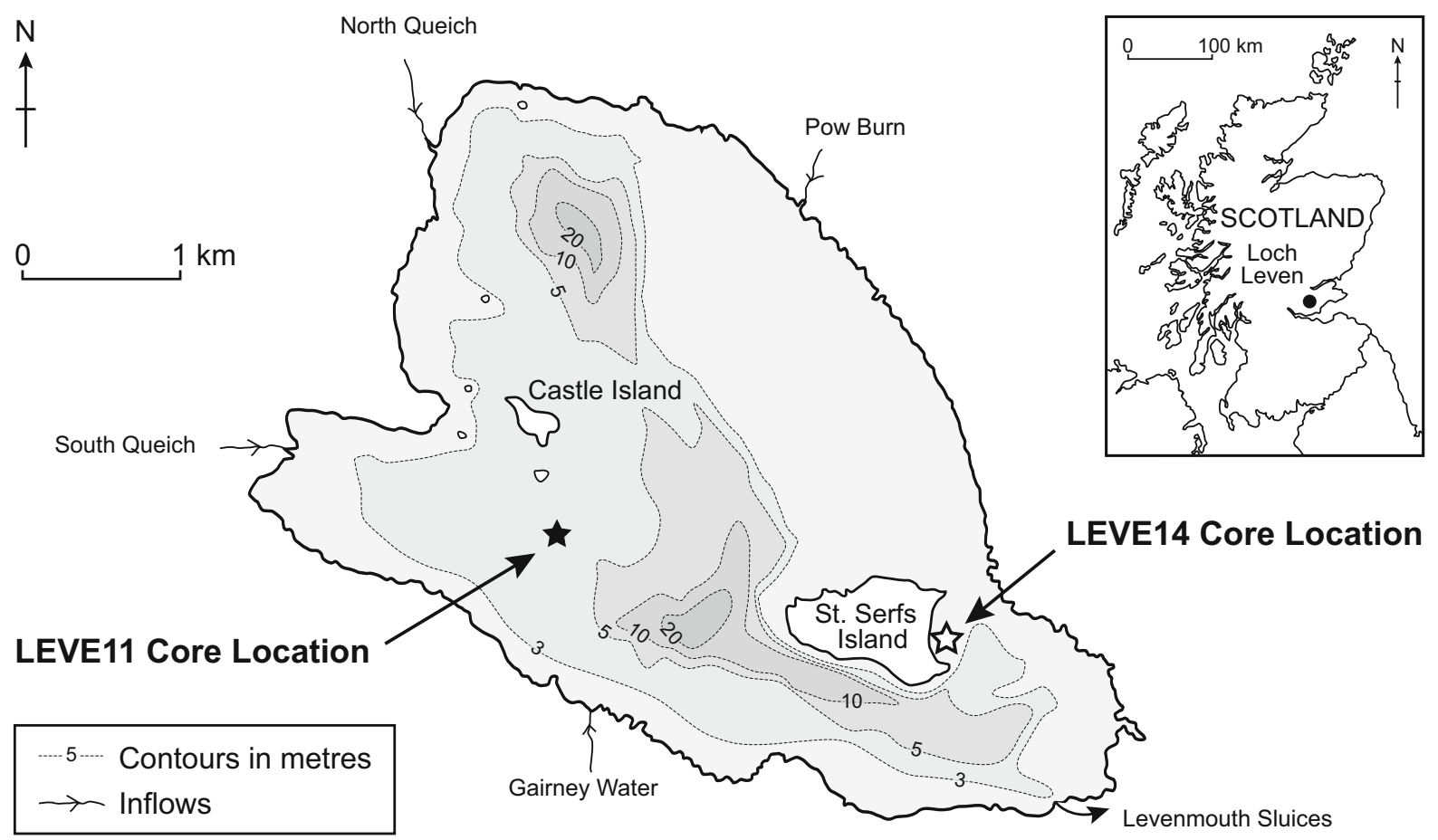

Fig. 1 Map showing the location and bathymetry of Loch Leven and the locations of sediment cores from previous studies of plant macrofossils (LEVE14) (Salgado et al. 2010) and

Sediment and fossil analyses

Thirty-one samples were analysed for plant macrofossils and 51 for loss-on-ignition (LOI) from core LEVE14 by Salgado et al. (2010). Forty-two subsamples from core LEVE14 were selected and prepared for testate amoeba and particle size analyses $(2-\mathrm{cm}$ intervals above $50 \mathrm{~cm}$ and $4-10-\mathrm{cm}$ intervals below $50 \mathrm{~cm}$ ). In this study an additional 18 core samples were subjected to LOI analysis (Dean 1974) to match the other analyses undertaken in this study.

Preparation of testate amoebae followed established protocols, previously developed for lake testate amoebae (Patterson and Kumar 2002). Samples of $0.5 \mathrm{~cm}^{3}$ were agitated for one hour using a platform shaker to separate cohesive sediments, and wet-sieved though $300 \mu \mathrm{m}$ and $37 \mu \mathrm{m}$ meshes to remove coarse organics and fine silts and clays. Although sieve sizes as small as $15 \mu \mathrm{m}$ have been used to retain the smallest of specimens in peatland studies (Swindles et al. 2009), $37 \mu \mathrm{m}$ is generally accepted as an appropriate sieve size to retain the majority of lake taxa (Patterson and Kumar 2000b). diatoms (LEVE11) (Bennion et al. 2012). Core LEVE14 is used in this study for testate amoeba analysis

This size fraction was also chosen to ensure comparability with recent lacustrine studies (Qin et al. 2009; Roe et al. 2010; Nasser et al. 2016). The 37-300 $\mu \mathrm{m}$ sieved residues were split into eight aliquots using a wet-splitter (Scott and Hermelin 1993) and fossil testate amoebae were quantified in aqueous solution using a Nikon light dissection binocular microscope at $\times 50-63$ magnification.

Testate amoebae have been shown to display significant amounts of ecophenotypic morphological variability (Medioli et al. 1987). Following many previous lake studies (Asioli et al. 1996; Patterson and Kumar 2000a; Kihlman and Kauppila 2012; Roe and Patterson 2014), a strain-based nomenclature was implemented. Morphotypes of the same species are designated informal 'strain' names to avoid potentially unwarranted descriptions of new species (Asioli et al. 1996; Patterson and Kumar 2002). Although these 'strains' are not formally recognised under the International Code of Zoological Nomenclature, many studies have proved their worth in terms of ecological indication (Boudreau et al. 2005; Escobar et al. 2008; Roe et al. 2010; Nasser et al. 2016). Testate amoebae 
were identified with reference to published scanning electron micrographs (Roe et al. 2010; Patterson et al. 2012), illustrations (Medioli and Scott 1983) and lacustrine testate amoebae keys (Kumar and Dalby 1998). Where possible, and to gain statistically significant counts, $>150$ specimens were quantified per sample (Patterson and Fishbein 1989; Wall et al. 2010a). Selected specimens were mounted for scanning electron micrograph (SEM) imaging, obtained using a JEOL 6500 FEG SEM at Queen's University Belfast Electron Microscopy Unit and a Tescan VegaII XMU VP SEM at Carleton University, Ottawa Nano Imaging Facility (Fig. 2).

To investigate the influence of changing sediment composition on testate amoeba assemblages, particle size distributions ( $\%$ sand, silt, clay) were determined by laser diffraction using a Malvern Mastersizer-2000. Sediments were treated with a hydrogen peroxide $\left(\mathrm{H}_{2} \mathrm{O}_{2}\right)$ digestion to remove organic matter prior to analysis (van Hengstum et al. 2007). Samples were subsequently rinsed in de-ionised water, centrifuged and the supernatant was decanted. Subsamples of the treated sediment were ultrasonically disaggregated and analysed by laser diffraction.

\section{Data analysis}

Testate amoeba counts were converted to relative abundance and plant macrofossil data standardised as concentrations (per $100 \mathrm{~cm}^{3}$ ). The construction and zonation of stratigraphic diagrams was performed using TILIA and TILIAGRAPH (Grimm 1991). Zones were identified for testate amoeba and plant macrofossil assemblages using constrained incremental sum of squares (CONISS) cluster analysis (Grimm 1987). In accordance with Birks (1986), only testate amoeba taxa $>5 \%$ abundance were included in the analysis.

Indicator taxa were identified for each stratigraphic zone in the testate amoeba assemblage using the IndVal procedure of Dufrêne and Legendre (1997). Those taxa retained had significant $(p<0.05)$ IndVal $_{j}$ scores based on permutation tests with 1000 random iterations.

To measure changes in testate amoeba taxonomic diversity over time, the Shannon Diversity Index (SDI) was applied (Shannon 1948). Environments are considered stressed where SDI is $<1.5$, in transition between 1.5 and 2.5 and stable between 2.5 and 3.5 (Magurran 1988; Patterson and Kumar 2000b). The counting of entire aliquots to determine testate amoeba sample concentrations can result in different count sizes above the minimum threshold of 150 . To check whether this caused variation in the SDI values, the testate amoeba data were subjected to rarefaction (Birks 2012) and standardised to 150 specimens per sample. The rarefied samples were found to display very similar SDI values to those derived from the original counts (ESM2), suggesting that variations in count sizes above the minimum threshold of 150 do not significantly bias the SDI values. Consequently, the original SDI values were retained.

Following an initial detrended correspondence analysis (DCA) of both the plant macrofossil and testate amoeba data, axis 1 gradient lengths for both groups were $2.7 \mathrm{SD}$ and $3.2 \mathrm{SD}$, respectively. Species' responses were therefore not seen to be unimodal (Lepš and Šmilauer 2003) and principal components analysis (PCA) was chosen as an appropriate method of ordination to determine major gradients of change within the biological assemblages. To make the data suitable for Euclideanbased ordination methods (Legendre and Birks 2012), plant macrofossil concentrations and the testate amoeba relative abundance data were subjected to a Hellinger transformation (Legendre and Gallagher 2001). The differential production of plant macrofossils (for example, leaf remains versus seeds) can lead to an imbalanced representation in palaeoecological records. Therefore, the plant macrofossil data were centred and standardised in order to reduce any potential asymmetry in the data. Significant PCA axes were identified using the broken stick model (Jackson 1993).

All statistical analyses were performed in $\mathrm{R}$ version 3.3.2 (R Development Core Team 2016) using the vegan (Oksanen et al. 2017) and labdsv (Roberts 2016) packages.

\section{Results}

Core chronology

The results of the AMS ${ }^{14} \mathrm{C}$ analyses are given in ESM 1. The bulk sediment AMS ${ }^{14} \mathrm{C}$ date from 68 to $69 \mathrm{~cm}$ $(1882 \pm 37$ year BP) predates the charcoal sample from 96 to $97 \mathrm{~cm}(827 \pm 34$ year BP), which may 

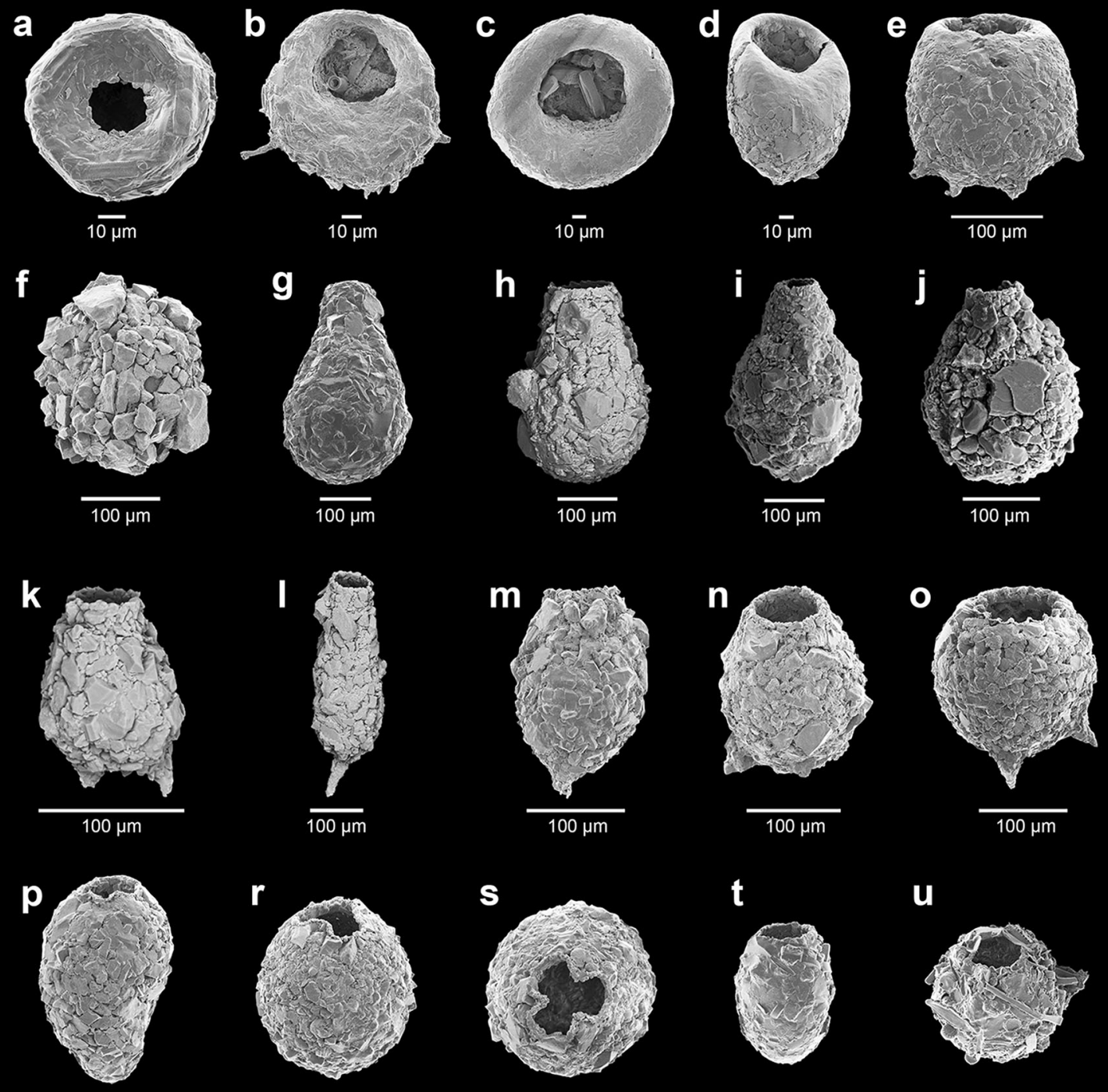

$10 \overline{\mu m}$

$10 \overline{\mu m}$

$10 \overline{\mu m}$
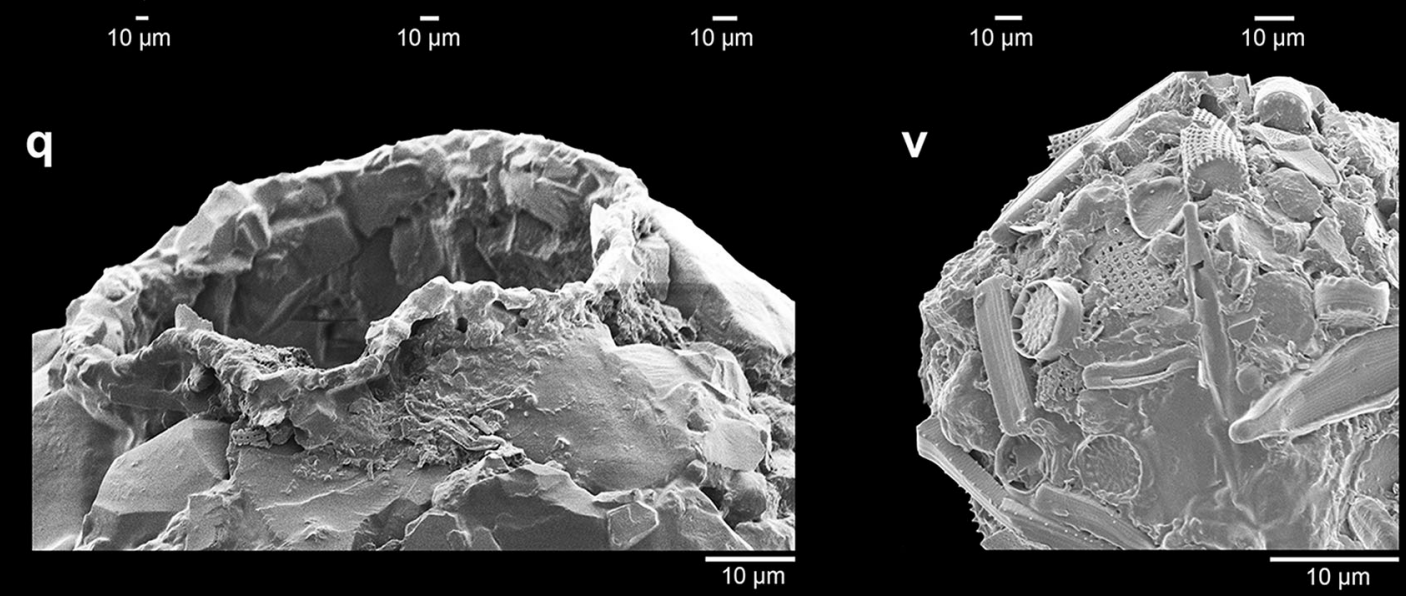
4Fig. 2 a-v: Scanning electron micrographs of selected testate amoeba specimens from Loch Leven (core LEVE14). a $C y$ clopyxis kahli Deflandre 1912. b Centropyxis aculeata (Ehrenberg 1832) strain "aculeata". c Centropyxis aculeata (Ehrenberg 1832) strain "discoides". d Centropyxis constricta (Ehrenberg 1843) strain "aerophila". e Centropyxis constricta (Ehrenberg 1843) strain "constricta". f Encysted Difflugia sp. test. g Difflugia oblonga Ehrenberg 1832 strain "oblonga". h Difflugia oblonga Ehrenberg 1832 strain "tenuis". i Lagenodifflugia vas Leidy 1874. j Pontigulasia compressa (Carter 1864). k Difflugia elegans Penard 1890. I Difflugia protaeiformis Lamarck 1816 strain "claviformis". m Difflugia glans Penard 1902 strain "distenda". n Difflugia glans Penard 1902 strain "glans". o Mediolus corona (Wallich 1864). p, q Difflugia amphora (Leidy 1874). p lateral view of entire specimen. $\mathbf{q}$ characteristic lobed aperture. r, $\mathbf{s}$ Cucurbitella tricuspis Carter 1856. $\mathbf{r}$ lateral view of entire specimen. $\mathbf{s}$ apertural view of specimen showing characteristic lobed aperture. t Difflugia lithophila Penard 1902. u, v Difflugia angulostoma GauthierLièvre and Thomas 1958. u entire specimen. $\mathbf{v}$ test surface composed predominantly of diatom frustules

reflect contamination of the bulk sediment sample by older carbon. Similarly, the bulk date from 134 to $135 \mathrm{~cm}(2420 \pm 34$ year BP) is much older than expected based on the extrapolation of ${ }^{210} \mathrm{~Pb}$-inferred sedimentation rates from the late $1920 \mathrm{~s}$ $\left(0.27 \mathrm{~cm} \mathrm{year}^{-1}\right)$, which would give a basal date of AD 1492 (Salgado et al. 2010). While the charcoal sample from 96 to $97 \mathrm{~cm}$ indicates that the core base may indeed be older than the estimated age, the sedimentation rate for the basal section of the core, indicated by the bulk date from 134 to $135 \mathrm{~cm}$ is too low $\left(0.04 \mathrm{~cm} \mathrm{year}^{-1}\right)$ for the latter date to be correct. As a result, only the date from the charcoal sample at 96-97 cm is included in the stratigraphic diagrams, in addition to the ${ }^{210} \mathrm{~Pb}$ dates from Salgado et al. (2010).

Testate amoeba assemblages

The preservation of fossil testate amoebae was good in all samples enabling counts of $>150$ specimens, and in many cases $>200$ specimens, to be achieved. Interpretation of the CONISS cluster analysis resulted in identification of four testate amoeba assemblage zones (Fig. 3): LLTA-1 (Loch Leven testate amoeba 1), LLTA-2, LLTA-3 and LLTA-4. The assemblage composition of these zones is described below and compared to corresponding changes in lithostratigraphy and the plant macrofossils (Fig. 4). The results of the IndVal analysis (Table 1) reveal a number of significant indicator taxa for each of the four zones identified by CONISS. Those with the highest indicator values $\left(I n d V a l_{j}\right)$ are highlighted within their respective zones below.

\section{LLTA-1 (139-94 cm)}

The sediments of this zone are characterised by silty gyttja, which becomes less organic (LOI $=1-11 \%$ ) and sandier towards the boundary with LLTA-2. The preservation of fossil testate amoebae is good (177-1522 specimens $\mathrm{cm}^{-3}$ ) and diversity (SDI = 1.9-2.3) can be classed as intermediate (Patterson and Kumar 2000b). The assemblage is characterised by a dominance of Difflugia oblonga Ehrenberg 1832 strain "oblonga" (25-43\%) and a mixture of difflugid and centropyxid taxa (Fig. 3). Throughout this zone, proportions of Centropyxis aculeata (Ehrenberg 1832) strain "discoides" (9-25\%) and Difflugia glans Penard 1902 strain "glans" (6-20\%) fluctuate, while Centropyxis aculeata (Ehrenberg 1832) strain "aculeata" declines from a peak of $22 \%$ at $128 \mathrm{~cm}$ to $8 \%$ at the zone boundary. Other centropyxid and difflugid taxa are present in lesser abundances (typically <5\%), as are Heleopera sphagni (Leidy 1874), Cyclopyxis kahli Deflandre 1912, Lagenodifflugia vas Leidy 1874, Pontigulasia compressa (Carter 1864) and Plagiopyxis disclivis Bonnet 1955. Of those identified as significant $(p<0.05)$ by IndVal, H. sphagni $\left(\right.$ IndVal $\left._{j}=0.67\right)$ and $D$. oblonga "oblonga" $\left(\right.$ IndVal $\left._{j}=0.46\right)$ have the highest indicator values (Table 1).

\section{Zone LLTA-2 (94-41 cm)}

Sediment organic matter increases compared to LLTA-1 and varies between 1 and 10\% throughout LLTA-2, while proportions of silt and sand fluctuate, indicating a less stable benthic environment. Difflugia oblonga "oblonga" (8-31\%) remains dominant, although proportions decline at $60 \mathrm{~cm}$ and $42 \mathrm{~cm}$ to 10 and $8 \%$, respectively. Centropyxid taxa, namely $C$. aculeata "aculeata" (6-27\%) and C. aculeata "discoides" (4-14\%), also fluctuate and remain in lesser proportions. However, compared to the previous zone, diversity (SDI $=2.2-2.6)$ and test concentrations (628-2272 specimens $\mathrm{cm}^{-3}$ ) increase and there are notable expansions in Difflugia oblonga Ehrenberg 1832 strain "tenuis" (4-16\%) as well as Difflugia elegans Penard 1890 (0-6\%), L. vas (1-10\%), Centropyxis constricta (Ehrenberg 1843) strain 


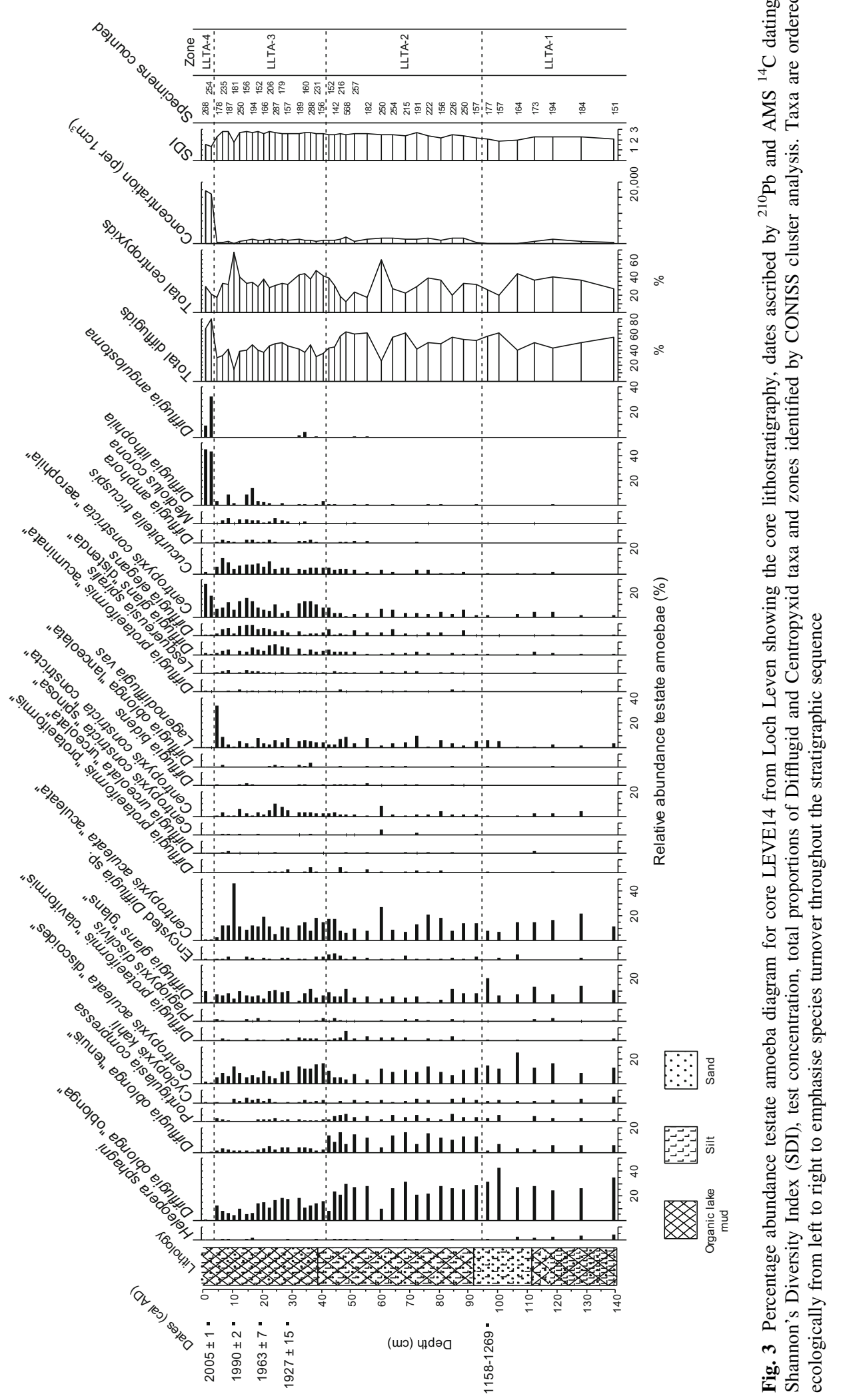



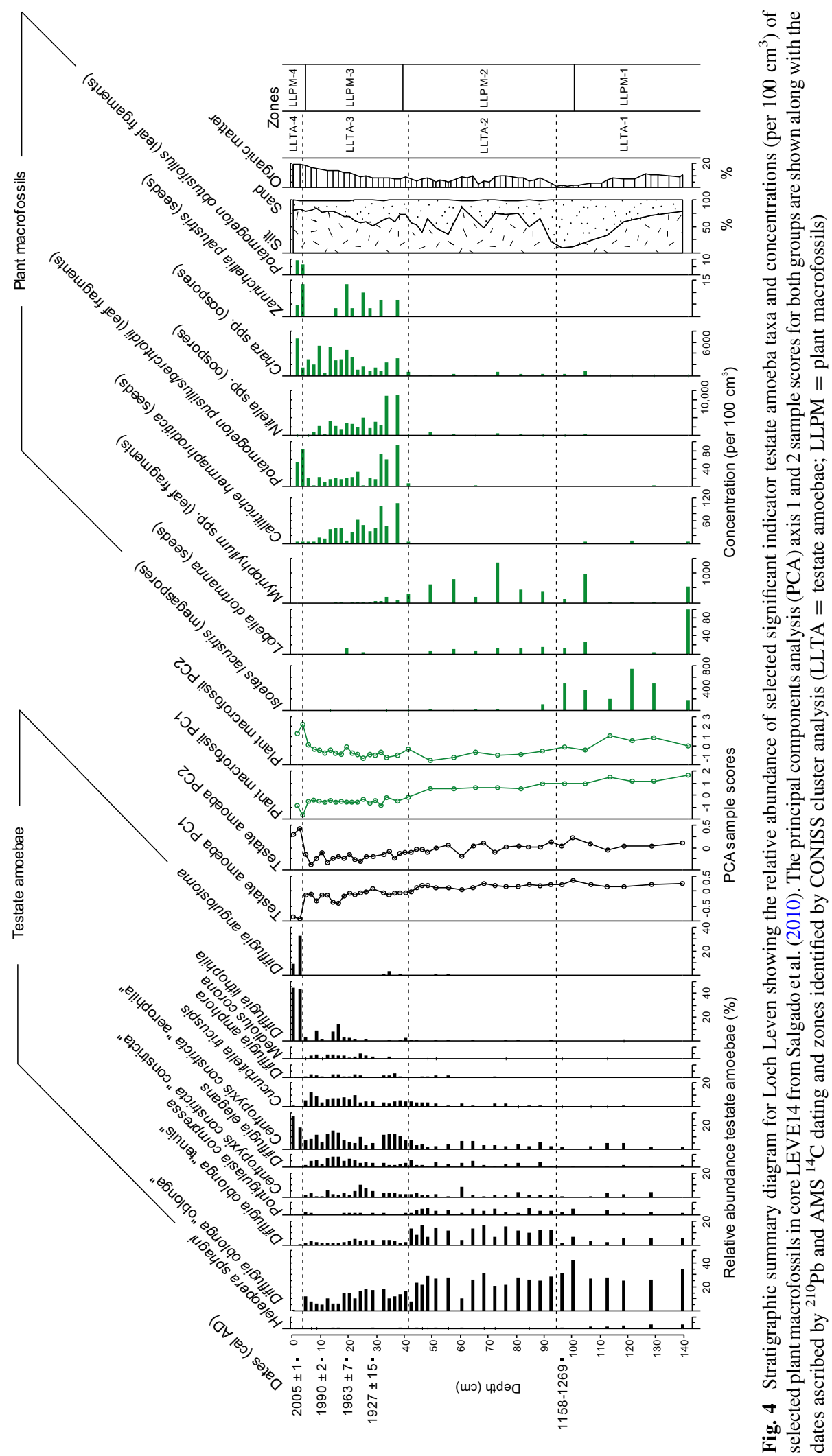
Table 1 The indicator value $\left(\right.$ Indval $\left._{j}\right)$ and significance of indicator taxa associated with the four stratigraphic zones in core LEVE14
Significance level:

$* * * p \leq 0.001$,

$* * p=0.001-0.01$,

$* p=0.01-0.05$

\begin{tabular}{llll}
\hline Taxa & Group (Zone) & IndVal $_{j}$ & Significance ( $p$ value) \\
\hline Heleopera sphagni & LLTA-1 & 0.6669 & $0.008^{* *}$ \\
Difflugia oblonga "oblonga" & LLTA-1 & 0.4590 & $0.001^{* * *}$ \\
Centropyxis aculeata "discoides" & LLTA-1 & 0.4289 & $0.002^{* *}$ \\
Cyclopyxis kahli & LLTA-1 & 0.4215 & $0.048^{*}$ \\
Difflugia glans "glans" & LLTA-1 & 0.3809 & $0.031^{*}$ \\
Difflugia oblonga "tenuis" & LLTA-2 & 0.6157 & $0.001^{* * *}$ \\
Difflugia protaeiformis "claviformis" & LLTA-2 & 0.5464 & $0.04^{*}$ \\
Pontigulasia compressa & LLTA-2 & 0.5104 & $0.001^{* * *}$ \\
Mediolus corona & LLTA-3 & 0.7390 & $0.001^{* * *}$ \\
Difflugia amphora & LLTA-3 & 0.6459 & $0.004^{* *}$ \\
Cucurbitella tricuspis & LLTA-3 & 0.6440 & $0.001^{* * *}$ \\
Difflugia elegans & LLTA-3 & 0.5167 & $0.001^{* * *}$ \\
Difflugia glans "distenda" & LLTA-3 & 0.4970 & $0.009^{* *}$ \\
Centropyxis constricta "constricta" & LLTA-3 & 0.4874 & $0.027^{*}$ \\
Lesquereusia spiralis & LLTA-3 & 0.4665 & $0.044^{*}$ \\
Difflugia angulostoma & LLTA-4 & 0.9823 & $0.001^{* * *}$ \\
Difflugia lithophila & LLTA-4 & 0.9280 & $0.001^{* * *}$ \\
Centropyxis constricta "aerophila" & LLTA-4 & 0.5883 & $0.001^{* * *}$ \\
\hline & & & \\
\hline
\end{tabular}

"aerophila" (1-8\%), P. compressa (2-6\%) and Difflugia protaeiformis Lamarck 1816 strain "claviformis" (0-7\%). Cucurbitella tricuspis Carter 1856 $(0-5 \%)$ is also present and increases in abundance towards the top of the zone. Difflugia oblonga "tenuis" $\left(\right.$ IndVal $\left._{j}=0.62\right)$, D. protaeiformis "claviformis" $\quad\left(\right.$ IndVal $\left._{j}=0.55\right)$ and P. compressa $\left(\right.$ IndVal $\left._{j}=0.51\right)$ are identified as significant indicator taxa according to IndVal.

\section{Zone LLTA-3 (41-3 cm)}

There is a gradual change in the lithostratigraphy in this zone as the sediments become less sandy and more organic (LOI $=7-19 \%$ ) towards the top of the core. A concurrent shift in the testate amoeba assemblages is also observed. Compared to previous zones, diversity again increases (SDI $=1.7-2.8$ ) and test concentrations decrease (207-1648 specimens $\mathrm{cm}^{-3}$ ). Difflugia oblonga "oblonga" decreases in abundance (5-19\%), but co-dominates with $C$. aculeata "aculeata" (3-46\%), C. aculeata "discoides" (5-17\%) and $C$. constricta "aerophila" (3-15\%). These centropyxid taxa display broadly synchronous fluctuations throughout LLTA-3. There are also notable expansions compared to LLTA-2 in Difflugia glans Penard 1902 strain "distenda" (0-8\%) and Difflugia lithophila
Penard 1902 (0-14\%). Cucurbitella tricuspis (3-12\%) gradually increases in abundance towards the top of the core, with peaks at 22 and $6 \mathrm{~cm}$. The relative abundance of Mediolus corona (Wallich 1864) (0-5\%) and Difflugia amphora (Leidy 1874) (0-3\%) also increase, while $P$. compressa (0-2\%) and D. oblonga "tenuis" (1-5\%) decrease. Of the taxa identified as significant by IndVal, M. corona $\left(\right.$ IndVal $\left._{j}=0.74\right), D$. amphora $\left(\right.$ IndVal $\left._{j}=0.65\right)$ and $C$. tricuspis $\left(I n d V a l_{j}=0.64\right)$ have the highest indicator values.

\section{Zone LLTA-4 (3-0 cm)}

The lithostratigraphy remains similar to the top of the previous zone, comprising organic silty gyttja $(\mathrm{LOI}=$ ca. $20 \%)$. However, a significant change in the testate amoeba assemblage occurs. There is a 15-fold increase in test concentrations (about 16,500 specimens $\mathrm{cm}^{-3}$ ) compared to LLTA-3 and diversity decreases substantially (SDI $=1.3$ and 1.6 ). In contrast to the previous zones, three smaller taxa dominate the assemblage, D. lithophilia (43-45\%), Difflugia angulostoma Gauthier-Lièvre and Thomas 1958 (9-33\%) and C. constricta "aerophila" (18-27\%). Difflugia glans "glans" (1-10\%) remains present, along with $C$. aculeata "aculeata" and C. aculeata "discoides", but in much smaller proportions $(<2 \%)$, 
and there are substantial decreases in the relative abundances of all other difflugid and centropyxid taxa compared to LLTA-3. Difflugia lithophila $\left(\right.$ IndVal $\left._{j}=0.98\right)$, D. angulostoma $\left(\operatorname{IndVal}_{j}=0.93\right)$ and C. constricta "aerophila" (IndVal $\left.{ }_{j}=0.59\right)$ are identified as significant indicator taxa according to IndVal.

Comparisons with plant macrofossil assemblages

A summary diagram that includes key plant macrofossil and testate amoeba data from core LEVE14 is given in Fig. 4. The diagram is divided into four zones (dashed lines), based on CONISS cluster analysis of the testate amoeba data. Interpretation of an additional CONISS cluster analysis of the plant macrofossil data resulted in the identification of four zones, prefixed with LLPM (Fig. 4). When compared, the zone boundaries of both groups are closely aligned, particularly at around $40 \mathrm{~cm}$ and $3 \mathrm{~cm}$. The lower zone boundaries at $94 \mathrm{~cm}$ and $101 \mathrm{~cm}$, for testate amoebae and plant macrofossils respectively, are slightly offset. Exact relative timings of community changes based on the zone boundaries are not possible due to different sample positions and resolutions between the groups analysed.

Testate amoeba zone LLTA-1 predates ca. AD 1200 and corresponds with an oligo-mesotrophic macrophyte assemblage (Salgado et al. 2010) dominated by isoetid plants, I. lacustris and Lobelia dortmanna, with the additional presence of Myriophyllum spp. The shift from sandy to siltier gyttja and a more diverse and abundant testate amoeba community in zone LLTA-2 after ca. AD 1200 is accompanied by increased concentrations of elodeid and charophyte taxa, namely Myriophyllum spp., Chara spp. and Nitella spp. A reduced concentration of I. lacustris and $L$. dortmanna are indicative of the progression of eutrophication in Loch Leven. Increased organic matter content and testate amoeba diversity in zone LLTA-3 is synchronous with a rapid increase in the concentration of charophyte oospores and leaf fragments of fine-leaved Potamogeton spp. The remains of other elodeid taxa, namely Zannichellia palustris and Callitriche hermaphroditica, also increase, while the concentration of isoetid remains are further reduced compared to the previous zone. These changes are thought to represent increasingly eutrophic and shallower lake conditions (Salgado et al. 2010), following lowering of the lake water levels ca. 1830. Testate amoeba zone LLTA-4 (ca. 2004-2006) comprises only two samples and corresponds with a macrophyte assemblage dominated by Chara spp., Potamogeton spp. and Z. palustris. In particular, Potamogeton obtusifolius is unique to the upper $4 \mathrm{~cm}$.

\section{Principal components analysis}

The total variance in the testate amoeba and plant macrofossil assemblages identified by PCA was 19.7 and $14.0 \%$ respectively (Fig. 4). Using the broken stick model (Jackson 1993), four principal component (PC) axes were identified as significant for testate amoebae $\left(\lambda_{1}=0.343, \lambda_{2}=0.153, \lambda_{3}=0.095\right.$ and $\left.\lambda_{4}=0.069\right)$ and two for plant macrofossils $\left(\lambda_{1}=0.356\right.$ and $\left.\lambda_{2}=0.174\right)$. The PC axis 1 and 2 sample scores for the testate amoeba and plant macrofossil assemblages are given in Fig. 4. These indicate synchronous compositional changes between the two groups, particularly around $113 \mathrm{~cm}$ and in the uppermost $4 \mathrm{~cm}$.

The plant macrofossil PCA bi-plot (Fig. 5a) emphasises that zone LLPM-1 is associated with isoetid plants, namely, I. lacustris and L. dortmanna, and varying proportions of organic matter. The transition to LLPM-2 is characterised by a strong association with Myriophyllum spp. and L. dortmanna, with moderate amounts of organic matter. In addition, zones LLPM-3 and LLPM-4 and their associations with elodeid and charophyte macrofossils and more organic sediments suggest compositionally distinctive eutrophic macrophyte assemblages. The ordering of assemblage zones along PC1 suggests this axis represents a strong eutrophic gradient in the plant macrofossil data.

Interpretation of the testate amoeba PCA bi-plot (Fig. 5b) indicates that $\mathrm{PC} 1$ shows a strong positive association with strains of $D$. oblonga, while PC2 shows a strong negative correlation with $C$. tricuspis. Furthermore, there is a distinct grouping of the LLTA3 samples scores which, based on comparisons with LLPM-3 and greater proportions of organic matter, suggests a distinct eutrophic assemblage. The distribution of samples scores along PC1 and PC2 suggests that either axis could represent a eutrophic gradient in the testate amoeba data. Indeed, the pattern indicates the influence of a strong secondary control that may co-vary with eutrophication. Lastly, the clustering of 


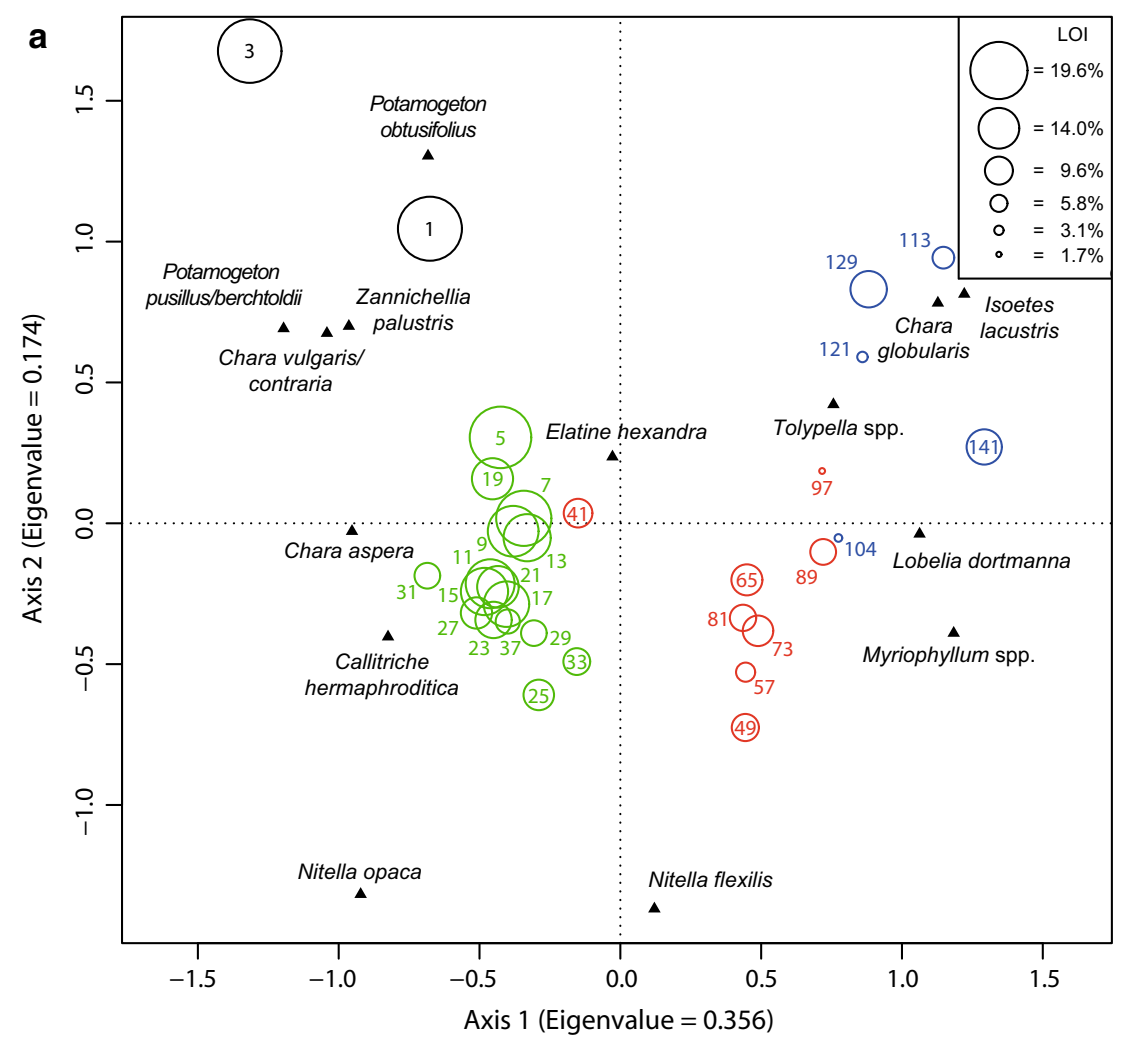

b

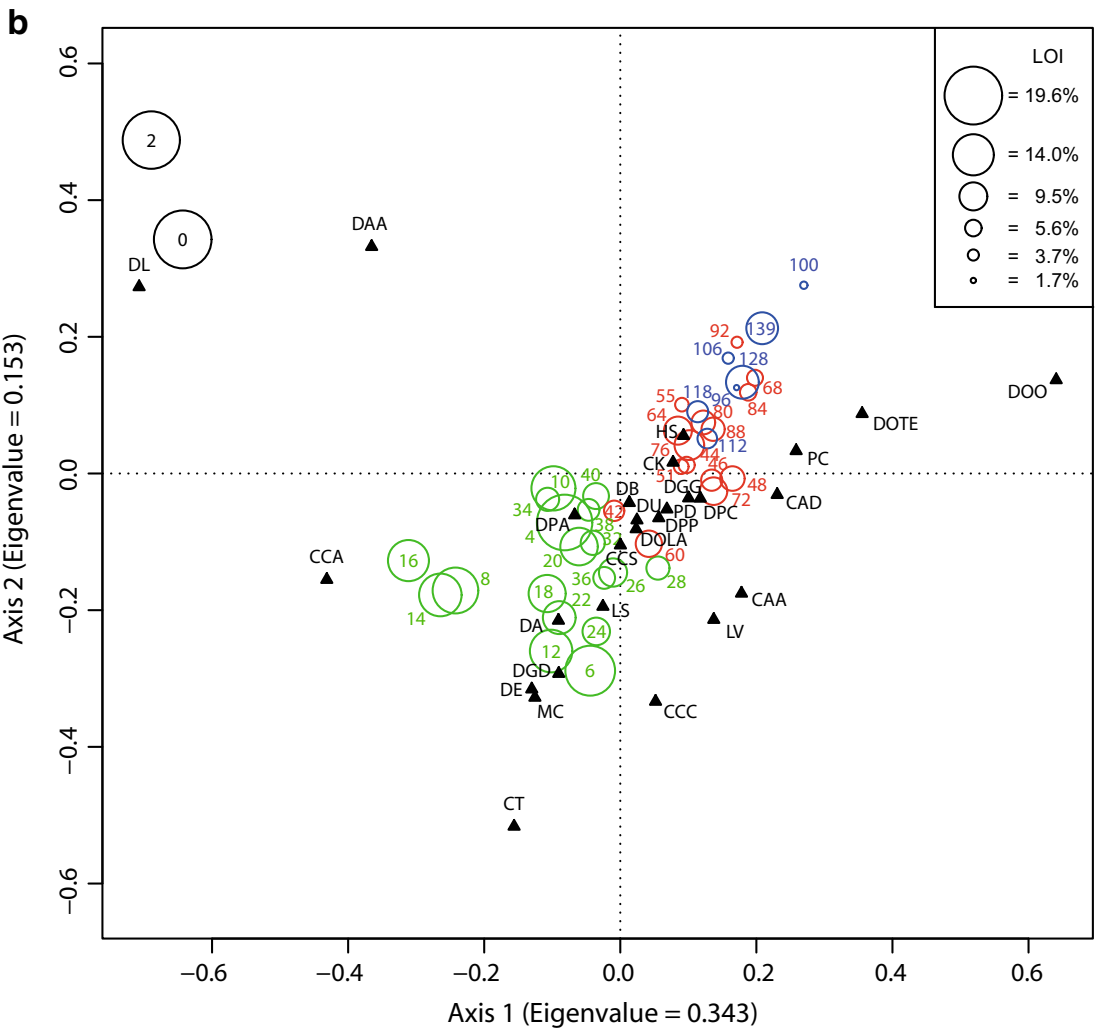


४Fig. 5 Principal components analysis (PCA) species-sample biplots for (a) plant macrofossils and (b) testate amoebae from core LEVE14. The assemblage zones identified by CONISS cluster analysis are highlighted according to colour (blue = LLPM-1 and LLTA-1; red = LLPM-2 and LLTA-2; green = LLPM-3 and LLTA-3; black = LLPM-4 and LLTA-4) and sample plotting symbol is proportional to percentage organic matter. $\mathrm{CAA}=$ Centropyxis aculeata (Ehrenberg 1832) strain "aculeata"; $\mathrm{CAD}=$ C. aculeata (Ehrenberg 1832) strain "discoides"; $\quad \mathrm{CCA}=C$. constricta (Ehrenberg 1843) strain "aerophila"; $\mathrm{CCC}=C$. constricta (Ehrenberg 1843) strain "constricta"; $\mathrm{CCS}=C$. constricta (Ehrenberg 1843) strain "spinosa"; CK = Cyclopyxis kahli Deflandre 1912; CT $=\mathrm{Cu}$ curbitella tricuspis Carter 1856; DA = Difflugia amphora (Leidy 1874); DAA = Difflugia angulostoma Gauthier-Lièvre and Thomas 1958; DB = Difflugia bidens Penard 1902; DE = Difflugia elegans Penard 1890; DGD = D. glans Penard 1902 strain "distenda"; DGG =D. glans Penard 1902 strain "glans"; $\mathrm{DL}=$ Difflugia lithophila Penard 1902; DOLA $=$ D. oblonga Ehrenberg 1832 strain "lanceolata"; DOO = D. oblonga Ehrenberg 1832 strain "oblonga"; DOTE $=D$. oblonga Ehrenberg 1832 strain "tenuis"; DPA $=$ D. protaeiformis Lamark 1816 strain "acuminata"; DPC = D. protaeiformis Lamark 1816 strain "claviformis"; DPP =D. protaeiformis Lamark 1816 strain "protaeiformis"; DU = D. urceolata Carter 1864 strain "urceolata"; HS = Heleopera sphagni (Leidy 1874); LS = Lesquereusia spiralis (Ehrenberg 1840); LV = Lagenodifflugia vas Leidy 1874; $\quad \mathrm{MC}=$ Mediolus corona (Wallich 1864); $\mathrm{PC}=$ Pontigulasia compressa Carter $1864 ; \mathrm{PD}=$ Plagiopyxis disclivis Bonnet 1955. (Color figure online)

both LLPM-4 and LLTA-4 confirms that these zones contain markedly different faunal assemblages compared to the other plant macrofossil and testate amoeba zones.

\section{Discussion}

Palaeo-inferred testate amoeba ecology

The oligo-mesotrophic macrophyte assemblage in zone LLTA-1, containing I. lacustris and L. dortmanna, is typical of many northern European freshwater lakes prior to nutrient-enrichment (Palmer et al. 1992). The corresponding testate amoeba assemblage is dominated by $D$. oblonga "oblonga", a common taxon which occurs in a range of lacustrine environments, from oligotrophic marl lakes (Wiik et al. 2015) to eutrophic kettle lakes (Roe et al. 2010). Strains of Difflugia are known to thrive in sediments rich in organic matter that are thought to sustain high population carrying capacities (Patterson and Kumar 2000a). They are therefore often abundant in lake gyttja (Collins et al. 1990; McCarthy et al. 1995), likely explaining their abundance in the Loch Leven palaeo-record. However, the organic matter variable on the PCA plot (Fig. 5b) indicates that D. oblonga "oblonga" is not associated with the most organic sediments in core LEVE14. Indeed, the peak abundance occurs around $100 \mathrm{~cm}$ where sediments are sandy and some of the least organic in the core (Fig. 4). This aligns with the findings of Torigai et al. (2000) who reported an abundance of D. oblonga in inorganic lake sediments from Lake Winnipeg, Canada. Overall, this suggests that this taxon can tolerate a wide range of sedimentary conditions and that multiple factors may influence its distribution.

Although $H$. sphagni was found in relatively low abundance $(<4 \%)$, it has the highest indicator value in the inferred oligo-mesotrophic zone (LLTA-1) and is therefore important to consider. Heleopera spp. are often associated with peat mosses like Sphagnum spp. (Schönborn 1967; Scott et al. 2001), but are also found in lake sediments (Ellison 1995; McCarthy et al. 1995; Wall et al. 2010b). During the earliest phase of the LEVE14 palaeo-record $H$. sphagni may therefore be associated with sub-littoral Sphagnum spp., which often occur in oligotrophic to mesotrophic lake conditions (Raven 1988; Palmer et al. 1992). Similarly, Schönborn (1962) finds Heleopera spp. in oligotrophic lake environments and reports them absent in more eutrophic lakes.

Cyclopyxis kahli is present throughout zone LLTA1 and often thought to be indicative of oligotrophic environments (Schönborn 1967; Wall et al. 2010b). However, despite fluctuations, the abundance of $C$. kahli remains relatively consistent throughout most of the palaeo-record despite a macrofossil-inferred transition in Loch Leven to mesotrophic and eutrophic conditions in zones LLTA-2 and LLTA-3 respectively. Others have reported this species in soil environments (Warner 1994) and some have suggested that its presence in lake sediments may indicate secondary derivation from terrestrial in-washing (Roe and Patterson 2006, 2014). Nonetheless, a loyal association of $C$. kahli with oligotrophic lake conditions is not verified by our data. The diversity and abundance of fossil testate amoebae found in zone LLTA-1 confirms that numerous species can withstand and thrive in oligo-mesotrophic conditions. This finding accords with previous work where oligotrophic and mesotrophic lakes dominated by 
Difflugid taxa display a similarly high diversity (SDI = approximately 2.1) (Roe and Patterson 2014).

The diatom record from core LEVE11 (Bennion et al. 2012), estimated to extend back about 700 years, includes a mixture of planktonic and periphytic taxa indicative of relatively stable oligotrophic to mesotrophic conditions. This is further substantiated by the mesotrophic plant assemblage identified in LLPM-2 (after ca. 1200 AD). As the depositional environment in zone LLTA-2 became predominantly silt-rich and organic matter increased, there was a corresponding shift to a more diverse and abundant testate amoeba community. Cucurbitella tricuspis, often cited as a eutrophic indicator taxon (Torigai et al. 2000; Reinhardt et al. 2005; Kihlman and Kauppila 2012) due to its association and symbiotic relationship with Spirogyra algae (Medioli et al. 1987; Patterson and Kumar 2002), increased in this zone. Difflugia oblonga "tenuis" and $P$. compressa are highly significant $(p<0.001)$ indicator taxa for this mesotrophic phase. Other palaeolimnological studies have also reported an abundance of $P$. compressa during inferred mesotrophic periods as delineated by pollen and NPP from Lake Simcoe, Canada (Volik et al. 2016) and Sluice Pond, USA (Drljepan et al. 2014). Thus, $P$. compressa may have an affinity for mesotrophic lake conditions. Variations in testate amoeba assemblage composition throughout LLTA-2 are highlighted by fluctuating PCA axis scores (Fig. 4). Given the known sensitivity of testate amoebae to changing substrate characteristics (Kihlman and Kauppila 2012), these changes may be linked to fluctuating proportions of sand and silt (Fig. 4) as well as the influence of eutrophication.

The continued eutrophication of Loch Leven throughout zone LLTA-3 (after ca. 1830) is evidenced by significant expansions of Potamogeton pusillus/ berchtoldii and Z. palustris, species that often dominate in highly eutrophic lakes (Sayer et al. 2010b; Bennion et al. 2015). This accords with the core LEVE11 diatom record (Bennion et al. 2012), which shows a marked shift to a planktonic dominated assemblage throughout the twentieth century, including Aulacoseira ambigua and Stephanodiscus hantzschii. Moreover, historical macrophyte surveys from 1905 to 2008 (Dudley et al. 2012b) attest to the continued eutrophication of Loch Leven during much of the twentieth century. Nutrient-enrichment was driven by increased inputs of TP to the loch which rose from an estimated $6 \mathrm{t} \mathrm{TP}$ year $^{-1}$ in the early 1900s to around $20 \mathrm{t} \mathrm{TP}_{\mathrm{Tear}}^{-1}$ in 1985 (May et al. 2012).

Concomitant changes in the testate amoeba community in zone LLTA-3 are evident as diversity again increases and D. oblonga "oblonga" no longer dominates the assemblage. A continued expansion of C. tricuspis during the twentieth century and a highly significant indicator value $(p<0.001)$ confirms that this taxon was associated with a more nutrientenriched lake. Furthermore, the introduction in this zone of two less abundant but statistically significant indicator taxa, D. amphora $(p<0.01)$ and M. corona $(p<0.001)$, is important to note. Tolonen (1986) provides an overview on the ecology of M. corona and $D$. amphora, both of which are linked to eutrophic conditions. These ecological inferences are in accordance with other studies from lakes in Ontario, Canada (Volik et al. 2016), Wuhan, China (Qin et al. 2009) and Massachusetts, USA (Drljepan et al. 2014) that report increases in the abundance of $M$. corona associated with nutrient enrichment. Conversely, D. amphora is rarely discussed in this regard.

The most significant point of change in the testate amoeba assemblage occurs in zone LLTA-4, which sees a substantial increase in test concentrations and much lowered diversity. Indeed, SDI values in this zone are at their lowest for all the samples in core LEVE14 which may indicate a more unstable and stressed environment (Patterson and Kumar 2000b). The distinct testate amoeba assemblage is dominated by $D$. angulostoma and D. lithophila, both of which have very high and significant $(p<0.001)$ indicator values. These taxa have been found in a range of lacustrine environments (Ellison 1995; Yang et al. 2005; Alves et al. 2010) and their presence has not been associated with any specific lake conditions. A number of possible factors may explain this distinctive surficial assemblage, including dissolution of these smaller specimens down-core or a significant recent alteration of the testate amoeba environment. As with most Arcellinida preserved in lakes, the tests of D. angulostoma and D. lithophila are composed of xenosomes. These types of test are thought to be the most robust (Lousier and Parkinson 1981), so it seems unlikely that differential dissolution might explain the observed pattern. The shift coincides with a significant plant assemblage change in the upper $4 \mathrm{~cm}$, as demonstrated by plant macrofossil PCA axis scores and the CONISS zone boundary. Indeed, Difflugiidae have shown an affinity for a range of 
microhabitats in lakes (Hardoim and Heckman 1996) and food preferences are also known to vary among taxa (Han et al. 2011). Therefore, a more suitable explanation may be a substantial change to the habitat in which they are living or to the microbial food-web, which favoured these smaller species, such as changing predation patterns, food availability and/or habitat structure. Additional research on lake testate amoeba taphonomy and habitat preferences is required in order to state more conclusively the cause of the observed changes.

When considered as a whole, the testate amoeba assemblages at Loch Leven showed gradual increases in diversity as the lake transitioned to mesotrophic and eutrophic conditions. This is consistent with other lake testate amoeba studies along eutrophic gradients. For example, Ju et al. (2014) reported a unimodal relationship for species diversity along a nutrient gradient for 51 lakes/reservoirs across China. Similarly, in the Yunnan Plateau, China, Yang et al. (2005) recorded the highest diversity of testate amoebae in mesotrophic lakes and the lowest in hypereutrophic lakes. Furthermore, a palaeolimnological study of Sluice Pond, Massachusetts, USA, (Drljepan et al. 2014) reported increased SDI values associated with eutrophication. However, given the different taxonomic approaches often used among testate amoeba researchers (Kosakyan et al. 2016), caution must be taken in directly comparing diversity between studies. This calls for a standardisation of taxonomic practices among lacustrine testate amoebae researchers in order to develop a coherent taxonomy that would increase the comparability of studies across wide spatial scales.

\section{Mechanisms of change}

A close alignment of zone boundaries and PCA axis scores of testate amoebae and plant macrofossils suggest that both groups are responding to nutrientenrichment, particularly since ca. 1830 . However, the plant macrofossils show a greater species turnover compared to the testate amoebae. Indeed, many taxa persist across the eutrophication gradient, such as $D$. oblonga "oblonga", D. glans "glans" and several centropyxid taxa. Given this more dampened signal, it is possible that the testate amoeba response to eutrophication could be partially indirect, driven by habitat changes associated with enrichment. This is supported by the distribution of sample scores in the testate amoeba PCA bi-plot (Fig. 5b) which suggests a strong secondary control on the assemblage that co-varies with eutrophication. In a palaeo-study of chironomid-macrophyte relationships from shallow, eutrophic Lake Søbygaard, Denmark (Brodersen et al. 2001), changing macrophyte assemblage structure was identified as a key likely driver of chironomid community changes. Given the range of lake microhabitats occupied by testate amoebae (Lansac-Tôha et al. 2014) and the synchronous response of both groups demonstrated here, it seems likely that similar relationships may also exist between testate amoebae and aquatic macrophytes.

Flößner et al. (1985) describe the diverse range of habitats occupied by testate amoebae in Lake Stechlin, Germany including not only the sediment but also the periphyton of submerged and floating leaved vegetation. Indeed, macrophytes are thought to provide a significant contribution to testate amoeba microhabitats in lakes (Alves et al. 2010), affording shelter from physical disturbance and increased structural complexity and habitat diversity (Lansac-Tôha et al. 2014). It must be considered, therefore, that any change in plant community structure might also impact the testate amoebae.

In addition to the taxa previously discussed as indicators for zone LLTA-3, D. elegans and $C$. constricta "constricta" were also identified as statistically significant in this respect (Table 1). Flößner et al. (1985) identified Centropyxis gibba (synonymous here with $C$. constricta "constricta") as inhabiting stands of Typha and Potamogeton, while D. elegans was found amongst beds of Characeae. Lansac-Tôha et al. (2014) also noted that D. elegans was a significant indicator of macrophytes, as opposed to sediment or open water habitats. The prevalence of D. elegans and C. constricta "constricta" in the eutrophic inferred zone (LLTA-3) may therefore be linked with increased macrophyte density associated with elodeid and charophyte vegetation development during the twentieth century.

Many testate amoebae, including D. oblonga and $P$. compressa are thought to be strongly associated with sediment microhabitats in lakes (Flößner et al. 1985; Alves et al. 2010; Lansac-Tôha et al. 2014). Occupying the benthos, these taxa will be sensitive to changes in substrate characteristics, including the oxygen status and biochemistry of the sediment water interface (Asioli et al. 1996; Roe et al. 2010; Kihlman and Kauppila 2012). It has been well documented that isoetid plants, such as L. dortmanna and I. lacustris, 
release oxygen via their roots during photosynthesis (Sand-Jensen et al. 1982; Smolders et al. 2002). This process, known as radial oxygen loss (Smolders et al. 2002), can increase sediment oxygen levels depending on the density of isoetid plants. The abundance of $I$. lacustris and, in particular, L. dortmanna throughout LLTA-1 and LLTA-2 may therefore facilitate favourable high oxygen conditions for sediment dwelling testate amoebae like $D$. oblonga "oblonga", $D$. oblonga "tenuis" and P. compressa, which are significant indicator taxa for these zones. In contrast, a sustained decline in isoetids and the proliferation of charophytes in zone LLTA-3 is coincident with lower abundances of strains of $P$. compress $a$ and strains of $D$. oblonga. A similar trend was noted by Wiik et al. (2015), who reported a decreased abundance of D. oblonga "oblonga" in a core from Cunswick Tarn (Cumbria, UK) during charophyte-dominated phases. Similarly, dense beds of Chara spp. have been shown to impact benthic chironomids, resulting in the exclusion of many bottom species under lower dissolved oxygen conditions (Tarkowska-Kukuryk and Kornijów 2008). This is due to strong oxygen consumption by microbes during the decomposition of dense beds of vegetation (Lindholm et al. 2008) and the reduced flow of water through charophyte meadows (Vermaat et al. 2000).

To confirm the aforementioned potential structuring mechanisms and determine the directness of the links between eutrophication, macrophytes and testate amoebae modern ecological work is clearly needed.

\section{Conclusions}

This study has employed palaeolimnological techniques to investigate the response of testate amoebae to nutrient enrichment in Loch Leven Scotland, a lake with a well-documented history of eutrophication. Comparisons of testate amoebae with plant macrofossil assemblages from the same core reveal synchronous compositional change across the two groups in response to nutrient enrichment. In addition, the indicator taxa identified for the eutrophic zone (post ca. AD 1830) confirm the previously determined ecological associations of C. tricuspis, M. corona and D. amphora with eutrophic lake conditions. We hypothesise that sediment dwelling testate amoeba such as D. oblonga “oblonga", D. oblonga "tenuis" and $P$. compressa are more abundant in oligo-mesotrophic and mesotrophic zones due to highly oxygenated sediment conditions, maintained by the presence of isoetid plants. We suggest that isoetid decline and a shift to high charophyte biomass during eutrophication (post ca. AD 1830) may have lowered sedimentary oxygen, reducing the abundance of benthic testate amoebae and giving rise to plant associated taxa like D. elegans and C. constricta "constricta". Our study highlights the key importance of considering macrophyte community succession and plant structure when interpreting fossil testate amoeba assemblages in lakes and demonstrates the value of using palaeoecology to inform ecology. Further research is needed to better understand the influence of aquatic macrophytes on testate amoebae and to examine other potential causal mechanisms of community change.

Acknowledgements This work was supported by a $\mathrm{PhD}$ studentship to SP from the Northern Ireland Department of Employment and Learning (DEL), which is gratefully acknowledged. Thanks are expressed to Paula Reimer of the

${ }^{14}$ Chrono Centre for Climate, the Environment and Chronology, Queen's University Belfast (QUB), for support with ${ }^{14} \mathrm{C}$ AMS dating. SEM photography was undertaken at the Queen's University Belfast Electron Microscopy Unit and the Carleton University, Ottawa Nano Imaging Facility, under the guidance of Stephen McFarland and Jianqun Wang respectively, to whom we express our thanks. We also thank Prof. R Timothy Patterson, Carleton University, Ottawa, and the students of his laboratory for help with taxonomic identification and statistical analysis. Travel to Ottawa was generously funded by a QUB William and Betty MacQuitty Travel Scholarship. The Departamento Administrativo de Ciencia, Tecnologia $e$ Innovación-COLCINECIAS supported J. Salgado under the postdoctoral program "Es tiempo de volver". Tom Davidson and two anonymous reviewers are thanked for their constructive comments on an earlier draft of the manuscript.

Open Access This article is distributed under the terms of the Creative Commons Attribution 4.0 International License (http:// creativecommons.org/licenses/by/4.0/), which permits unrestricted use, distribution, and reproduction in any medium, provided you give appropriate credit to the original author(s) and the source, provide a link to the Creative Commons license, and indicate if changes were made.

\section{References}

Alves GM, Velho LFM, Simões NR, Lansac-Tôha FA (2010) Biodiversity of testate amoebae (Arcellinida and Euglyphida) in different habitats of a lake in the Upper Paraná River floodplain. Eur J Protistol 46:310-318 
Amesbury MJ, Swindles GT, Bobrov A, Charman DJ, Holden J, Lamentowicz M, Mallon G, Mazei Y, Mitchell EAD, Payne RJ, Roland TP, Turner TE, Warner BG (2016) Development of a new pan-European testate amoeba transfer function for reconstructing peatland palaeohydrology. Quat Sci Rev 152:132-151

Anderson NJ, Rippey B, Gibson CE (1993) A comparison of sedimentary and diatom-inferred phosphorus profiles: implications for defining pre-disturbance nutrient conditions. Hydrobiologia 253:357-366

Asioli A, Medioli FS, Patterson RT (1996) Thecamoebians as a tool for reconstruction of paleoenvironments in some Italian lakes in the foothills of the southern Alps (Orta, Varese and Candia). J Foramin Res 26:248-263

Barnett RL, Newton TL, Charman DJ, Gehrels WR (2017) Saltmarsh testate amoebae as precise and widespread indicators of sea-level change. Earth Sci Rev 164:193-207

Bennion H, Simpson GL, Anderson NJ, Clarke G, Dong X, Hobaeæk A, Guilizzoni P, Marchetto A, Sayer CD, Thies H, Tolotti M (2011) Defining ecological and chemical reference conditions and restoration targets for nine European lakes. J Paleolimnol 45:415-431

Bennion H, Carvalho L, Sayer CD, Simpson GL, Wischnewski J (2012) Identifying from recent sediment records the effects of nutrients and climate on diatom dynamics in Loch Leven. Freshw Biol 57:2015-2029

Bennion H, Davidson TA, Sayer CD, Simpson GL, Rose NL, Sadler JP (2015) Harnessing the potential of the multiindicator palaeoecological approach: an assessment of the nature and causes of ecological change in a eutrophic shallow lake. Freshw Biol 60:1423-1442

Birks HJB (1986) Numerical zonation, comparison and correlation of Quaternary pollen-stratigraphical data. In: Berglund BE (ed) Handbook of Holocene Palaeoecology and Palaeohydrology. John Wiley \& Sons, Chichester, pp 743-774

Birks HJB (2012) Introduction and overview of part II. In: Birks HJB, Lotter AF, Juggins S, Smol JP (eds) Tracking Environmental Change Using Lake Sediments, vol 5. Data Handling and Numerical Techniques. Springer, Dordrecht, pp 101-121

Boudreau REA, Galloway JM, Patterson RT, Kumar A, Michel FA (2005) A paleolimnological record of Holocene climate and environmental change in the Temagami region, northeastern Ontario. J Paleolimnol 33:445-461

Brodersen KP, Whiteside MC, Lindegaard C (1998) Reconstruction off trophic state in Danish lakes using subfossil chydorid (Cladocera) assemblages. Can J Fish Aquat Sci 55:1093-1103

Brodersen KP, Odgaard BV, Vestergaard O, John Anderson N (2001) Chironomid stratigraphy in the shallow and eutrophic Lake Søbygaard, Denmark: chironomid-macrophyte co-occurrence. Freshw Biol 46:253-267

Brooks SJ, Bennion H, Birks HJB (2001) Tracing lake trophic history with a chironomid-total phosphorus inference model. Freshw Biol 46:513-533

Caffau M, Lenaz D, Lodolo E, Zecchin M, Comici C, Tassone A (2015) First evidence of testate amoebae in Lago Fagnano $\left(54^{\circ} \mathrm{S}\right)$, Tierra del Fuego (Argentina): proxies to reconstruct environmental changes. J South Am Earth Sci $64: 27-41$
Castle K, Frost CA, Flint D (1999) The Loch Leven projectbuffer strips in practice on a catchment scale. Asp Appl Biol 54:71-78

Collins ES, McCarthy FMG, Medioli FS, Scott DB, Honig CA (1990) Biogeographic distribution of modern Thecamoebians in a transect along the Eastern North American Coast. In: Hemleben C, Kaminski MA, Kuhnt W, Scott DB (eds) Paleoecology, biostratigraphy, paleoceanography and taxonomy of agglutinated foraminifera NATO ASI series, vol 327. Part 3. Springer, Dordrecht, pp 783-792

D’Arcy BJ, May L, Long J, Fozzard IR, Greig S, Brachet A (2006) The restoration of Loch Leven, Scotland, UK. Water Sci Technol 53:183-191

Davidson TA, Sayer CD, Bennion H, David C, Rose N, Wade MP (2005) A 250 year comparison of historical, macrofossil and pollen records of aquatic plants in a shallow lake. Freshw Biol 50:1671-1686

Davidson TA, Bennion H, Jeppesen E, Clarke GH, Sayer CD, Morley D, Odgaard BV, Rasmussen P, Rawcliffe R, Salgado J, Simpson GL, Amsinck SL (2011) The role of cladocerans in tracking long-term change in shallow lake trophic status. Hydrobiologia 676:299-315

Dean WEJ (1974) Determination of carbonate and organic matter in calcareous sediments and sedimentary rocks. J Sediment Petrol 44:242-248

Drljepan M, McCarthy FM, Hubeny JB (2014) Natural and cultural eutrophication of Sluice Pond, Massachusetts, USA, recorded by algal and protozoan microfossils. Holocene 24:1731-1742

Dudley BJ, Spears BM, Carvalho L, Gunn IDM, May L (2012a) Water quality monitoring at Loch Leven 2008-2010Report of results. Scottish Natural Heritage Commissioned Report No. 511

Dudley B, Gunn IDM, Carvalho L, Proctor I, O'Hare MT, Murphy KJ, Milligan A (2012b) Changes in aquatic macrophyte communities in Loch Leven: evidence of recovery from eutrophication? Hydrobiologia 681:49-57

Dufrêne M, Legendre P (1997) Species assemblages and indicator species: the need for a flexible asymmetrical approach. Ecol Monogr 67:345-366

Ellison RL (1995) Paleolimnological analysis of Ullswater using testate amoebae. J Paleolimnol 13:51-63

Escobar J, Brenner M, Whitmore TJ, Kenney WF, Curtis JH (2008) Ecology of testate amoebae (thecamoebians) in subtropical Florida lakes. J Paleolimnol 40:715-731

Flößner D, Kasprzak P, Mothes G, Ronneberger D, Schönborn W (1985) The invertebrate communities. In: Casper SJ (ed) Lake Stechlin: A temperate oligotrophic lake. Kluwer Academic Publishers, Dordrecht, pp 213-259

Gehrels WR, Roe HM, Charman DJ (2001) Foraminifera, testate amoebae and diatoms as sea-level indicators in UK saltmarshes: a quantitative multiproxy approach. J Quat Sci 16:201-220

Grimm EC (1987) CONISS: a FORTRAN 77 program for stratigraphically constrained cluster analysis by the method of incremental sum of squares. Computat Geosci 13:13-35

Grimm EC (1991) TILIA version 1.11. TILIAGRAPH version 1.18. Illinois State Museum, Springfield, USA

Han B-, Wang T, Xu L, Lin QQ, Jinyu Z, Dumont HJ (2011) Carnivorous planktonic Difflugia (Protista, Amoebina Testacea) and their predators. Eur J Protistol 47:214-223 
Hardoim EL, Heckman CW (1996) The seasonal succession of biotic communities in wetlands of the tropical wet-and-dry climatic zone: IV. The free-living sarcodines and ciliates of the Pantanal of Mato Grosso, Brazil. Int Rev Gesamten Hydrobiol 81:367-384

Haworth EY (1972) The recent diatom history of Loch Leven, Kinross. Freshw Biol 2:131-141

Jackson DA (1993) Stopping rules in principal components analysis: a comparison of heuristical and statistical approaches. Ecology 74:2204-2214

Ju L, Yang J, Liu L, Wilkinson DM (2014) Diversity and distribution of freshwater testate amoebae (Protozoa) along latitudinal and trophic gradients in China. Microb Ecol 68:657-670

Jupp BP, Spence DHN, Britton RH (1974) The distribution and production of submerged macrophytes in Loch Leven, Kinross. Proc R Soc Edinb Sect B 74:195-208

Kihlman S, Kauppila T (2012) Effects of mining on testate amoebae in a Finnish lake. J Paleolimnol 47:1-15

Kosakyan A, Gomaa F, Lara E, Lahr DJG (2016) Current and future perspectives on the systematics, taxonomy and nomenclature of testate amoebae. Eur J Protistol 55:105-117

Kowalewski GA, Kornijów R, McGowan S, Woszczyk M, Suchora M, Bałaga K, Kaczorowska A, Gasiorowski M, Szeroczyńska K, Wasiłowska A (2013) Persistence of protected, vulnerable macrophyte species in a small, shallow eutrophic lake (eastern Poland) over the past two centuries: implications for lake management and conservation. Aquat Bot 106:1-13

Kumar A, Dalby AP (1998) Identification key for Holocene lacustrine arcellacean (thecamoebian) taxa. Palaeontol Electron 1:4A

Laminger H (1973) Quantitative Untersuchung über die Testaceenfauna (Protozoa Rhizopoda) in den jungsten Bodensee-Sedimenten. Biologische Jaarboek 41:126-146

Lansac-Tôha FA, Velho LFM, Costa DM, Simões NR, Alves GM (2014) Structure of the testate amoebae community in different habitats in a neotropical floodplain. Braz J Biol 74:181-190

Legendre P, Birks HJB (2012) From classical to canonical ordination. In: Birks HJB, Lotter AF, Juggins S, Smol JP (eds) Tracking Environmental Change Using Lake Sediments, vol 5. Data Handling and Numerical Techniques. Springer, Dordrecht, pp 201-248

Legendre P, Gallagher ED (2001) Ecologically meaningful transformations for ordination of species data. Oecologia 129:271-280

Lepš J, Šmilauer P (2003) Multivariate Analysis of Ecological Data using CANOCO. Cambridge Press, Cambridge

Lindholm T, Rönnholm E, Häggqvist K (2008) Changes due to invasion of Myriophyllum sibiricum in a shallow lake in Åland, SW Finland. Aquat Invasions 3:10-13

Lousier JD, Parkinson D (1981) The disappearance of the empty tests of litter- and soil-testate amoebae (Testacea, Rhizopoda, Protozoa). Arch Protistenk 124:312-336

Magurran AE (1988) Ecological diversity and its measurement. Princeton University Press, Princeton

May L, Spears BM (eds) (2012) Loch Leven: 40 years of scientific research: Understanding the links between pollution, climate change and ecological response. Springer, London

May L, Defew LH, Bennion H, Kirika A (2012) Historical changes (1905-2005) in external phosphorus loads to Loch Leven, Scotland, UK. Hydrobiologia 681:11-21

McCarthy FM, Collins ES, McAndrews JH, Kerr HA, Scott DB, Medioli FS (1995) A comparison of postglacial arcellacean ("thecamoebian") and pollen succession in Atlantic Canada, illustrating the potential of arcellaceans for paleoclimatic reconstruction. J Paleontol 69:980-993

Medioli FS, Scott DB (1983) Holocene Arcellacea (thecamoebians) from eastern Canada. Cushman Found Spec Publ 21:5-63

Medioli FS, Scott DB, Abbott BH (1987) A case study of protozoan intraclonal variability; taxonomic implications. J Foramin Res 17:28-47

Morgan NC (1970) Changes in the fauna and flora of a nutrient enriched lake. Hydrobiologia 35:545-553

Nasser NA, Patterson RT, Roe HM, Galloway JM, Falck H, Palmer MJ, Spence C, Sanei H, Macumber AL, Neville LA (2016) Lacustrine Arcellinina (testate amoebae) as bioindicators of arsenic contamination. Microb Ecol 72:130-149

Oksanen J, Blanchet FG, Kindt R, Legendre P, O'Hara RB, Simpson GL et al. (2017) vegan: Community Ecology Package. R package version 2.4-2. https://cran.r-project. org/web/packages/vegan

Palmer MA, Bell SL, Butterfield I (1992) A botanical classification of standing waters in Britain: applications for conservation and monitoring. Aquat Conserv 2:125-143

Patterson RT, Fishbein E (1989) Re-examination of the statistical methods used to determine the number of point counts needed for micropaleontological quantitative research. J Paleontol 63:245-248

Patterson RT, Kumar A (2000a) Assessment of arcellacean (thecamoebian) assemblages, species, and strains as contaminant indicators in James Lake, Northeastern Ontario, Canada. J Foramin Res 30:310-320

Patterson RT, Kumar A (2000b) Use of arcellacea to gauge levels of pollution and remediation of industrially polluted lakes. In: Martin RE (ed) Environmental micropaleontology, topics in geobiology, vol 15. Kluwer Academic/Plenum Publication, New York, pp 257-278

Patterson RT, Kumar A (2002) A review of current testate rhizopod (thecamoebian) research in Canada. Palaeogeogr Palaeoclimatol Palaeoecol 180:225-251

Patterson RT, Roe HM, Swindles GT (2012) Development of an Arcellacea (testate lobose amoebae) based transfer function for sedimentary Phosphorus in lakes. Palaeogeogr Palaeoclimatol Palaeoecol 348-349:32-44

Patterson RT, Lamoureux EDR, Neville LA, Macumber AL (2013) Arcellacea (testate lobose amoebae) as pH indicators in a pyrite mine-acidified lake, Northeastern Ontario, Canada. Microb Ecol 65:541-554

Qin Y, Booth RK, Gu Y, Wang Y, Xie S (2009) Testate amoebae as indicators of 20th century environmental change in Lake Zhangdu, China. Fundam Appl Limnol 175:29-38

Quinlan R, Smol JP (2002) Regional assessment of long-term hypolimnetic oxygen changes in Ontario (Canada) shield lakes using subfossil chironomids. J Paleolimnol 27:249-260 
Raven PJ (1988) Occurrence of sphagnum moss in the sublittoral of several small oligotrophic lakes in Galloway, Southwest Scotland. Aquat Bot 30:223-230

R Development Core Team (2016) R: a language and environment for statistical computing. R Foundation for Statistical Computing, Vienna. http://www.R-project.org

Reinhardt EG, Little M, Donato S, Findlay D, Krueger A, Clark C, Boyce J (2005) Arcellacean (thecamoebian) evidence of land-use change and eutrophication in Frenchman's Bay, Pickering, Ontario. Environ Geol 47:729-739

Roberts DW (2016) labdsv: Ordination and Multivariate Analysis for Ecology. R package version 1.8-0. Available online at https://cran.r-project.org/web/packages/labdsv/labdsv.pdf

Roe HM, Patterson RT (2006) Distribution of thecamoebians (testate amoebae) in small lakes and ponds, Barbados, West Indies. J Foraminif Res 36:116-134

Roe HM, Patterson RT (2014) Arcellacea (testate amoebae) as bio-indicators of road salt contamination in lakes. Microb Ecol 68:299-313

Roe HM, Charman DJ, Gehrels WR (2002) Fossil testate amoebae in coastal deposits in the UK: implications for studies of sea-level change. J Quat Sci 17:411-429

Roe HM, Patterson RT, Swindles GT (2010) Controls on the contemporary distribution of lake thecamoebians (testate amoebae) within the Greater Toronto Area and their potential as water quality indicators. J Paleolimnol 43:955-975

Salgado J, Sayer C, Carvalho L, Davidson T, Gunn I (2010) Assessing aquatic macrophyte community change through the integration of palaeolimnological and historical data at Loch Leven, Scotland. J Paleolimnol 43:191-204

Sand-Jensen K, Prahl C, Stokholm H (1982) Oxygen release from roots of submerged aquatic macrophytes. Oikos 38:349-354

Sayer CD, Davidson TA, Jones JI, Langdon PG (2010a) Combining contemporary ecology and palaeolimnology to understand shallow lake ecosystem change. Freshw Biol 55:487-499

Sayer CD, Burgess A, Kari K, Davidson TA, Peglar S, Yang H, Rose N (2010b) Long-term dynamics of submerged macrophytes and algae in a small and shallow, eutrophic lake: implications for the stability of macrophyte-dominance. Freshw Biol 55:565-583

Sayer CD, Davidson TA, Rawcliffe R, Langdon PG, Leavitt PR, Cockerton G, Rose NL, Croft T (2016) Consequences of fish kills for long-term trophic structure in shallow lakes: implications for theory and restoration. Ecosystems 19:1289-1309

Schönborn W (1962) Die Ökologie der Testaceen im oligotrophen See, dargestellt am Beispiel des Grossen Stechlinsees. Limnologica 1:111-182

Schönborn W (1967) Taxozönotik des beschalten SüßwasserRhizopoden eine raumstruckturanalytische Untersuchung über Lebensraumerweiterung und Evolution bei der Mikrofauna. Limnologica 5:159-207

Schönborn W, Flössner D, Proft G (1965) Die Limnologische Characterisierung des Profundals einiger norddeutscher Seen mit Hilfe von Testaceen-Gemeinschaften. Limnologica 3:371-380

Scott DB, Hermelin JOR (1993) A device for precision splitting of micropaleontological samples in liquid suspension. J Paleontol 67:151-154
Scott DB, Medioli FS, Schafer CT (2001) Monitoring in Coastal Environments Using Foraminifera and Thecamoebian Indicators. Cambridge University Press, Cambridge

Shannon CE (1948) A mathematical theory of communication. Bell Syst Tech J 27:379-423

Smolders AJP, Lucassen ECHET, Roelofs JGM (2002) The isoetid environment: biogeochemistry and threats. Aquat Bot 73:325-350

Swindles GT, Charman DJ, Roe HM, Sansum PA (2009) Environmental controls on peatland testate amoebae (Protozoa: Rhizopoda) in the North of Ireland: Implications for Holocene palaeoclimate studies. J Paleolimnol 42:123-140

Tarkowska-Kukuryk M, Kornijów R (2008) Influence of spatial distribution of submerged macrophytes on chironomidae assemblages in shallow lakes. Pol J Ecol 56:569-579

Tolonen K (1986) Rhizopod analysis. In: Berglund BE (ed) Handbook of Holocene Palaeoecology and Palaeohydrology. Wiley, Chichester, pp 645-666

Torigai K, Schröder-Adams CJ, Burbidge SM (2000) A variable lacustrine environment in Lake Winnipeg, Manitoba: Evidence from modern thecamoebian distribution. J Paleolimnol 23:305-318

van Hengstum PJ, Reinhardt EG, Boyce JI, Clark C (2007) Changing sedimentation patterns due to historical land-use change in Frenchman's Bay, Pickering, Canada: evidence from high-resolution textural analysis. J Paleolimnol 37:603-618

Vermaat JE, Santamaria L, Roos PJ (2000) Water flow across and sediment trapping in submerged macrophyte beds of contrasting growth form. Arch Hydrobiol 148:549-562

Volik O, McCarthy FMG, Riddick NL (2016) Insights from pollen, non-pollen palynomorphs and testate amoebae into the evolution of Lake Simcoe. J Paleolimnol 56:137-152

Wall AAJ, Gilbert D, Magny M, Mitchell EAD (2010a) Testate amoeba analysis of lake sediments: impact of filter size and total count on estimates of density, species richness and assemblage structure. J Paleolimnol 43:689-704

Wall AAJ, Magny M, Mitchell EAD, Vannière B, Gilbert D (2010b) Response of testate amoeba assemblages to environmental and climatic changes during the LateglacialHolocene transition at Lake Lautrey (Jura Mountains, eastern France). J Quat Sci 25:945-956

Warner BG (1994) Effects of light, fertilizers and pesticides on shell size of the common freshwater and soil species $C y$ clopyxis kahli (Rhizopoda, Testacealobosia). Limnologica 24:333-338

Wiik E, Bennion H, Sayer CD, Davidson TA, Clarke SJ, McGowan S, Prentice S, Simpson GL, Stone L (2015) The coming and going of a marl lake: multi-indicator palaeolimnology reveals abrupt ecological change and alternative views of reference conditions. Front Ecol Evol 3:82

Yang J, Zhang W, Feng W, Shen Y (2005) Freshwater testate amoebae of nine Yunnan Plateau lakes, China. J Freshw Ecol 20:743-750

Zhang E, Cao Y, Langdon P, Jones R, Yang X, Shen J (2012) Alternate trajectories in historic trophic change from two lakes in the same catchment, Huayang Basin, middle reach of Yangtze River, China. J Paleolimnol 48:367-381 